(RESEARCH ARTICLE)

\title{
Proximate composition and nutritional value of three edible mushrooms ectomycorrhizal (Russula mustelina, Russula Delica and Russula Lepida) from Côte d'Ivoire according to the maturity stages
}

\author{
Jaures Gbotognon Oscar ${ }^{1}$, Appolinaire Kouassi Kouamé 2, Hubert Konan Kouassi 1, ${ }^{*}$ and Jean Parfait \\ Kouadio Eugène ${ }^{1}$

\begin{abstract}
${ }^{1}$ Laboratory of Biocatalysis and Bioprocesses, Faculty of Science and Food Technology, University Nangui Abrogoua (Abidjan, Ivory Coast), 02 BP 801 Abidjan 02, Ivory Coast.

2 Department of Biochemistry, Faculty of Biological Sciences, Péléforo Gon Coulibaly University (Korhogo, Ivory Coast) BP 1328, Korhogo, Ivory Coast.
\end{abstract}

Publication history: Received on 05 July 2018; revised on 30 July 2019; accepted on 31 July 2019

Article DOI: https://doi.org/10.30574/wjarr.2019.2.3.0040

\begin{abstract}
In Côte d'Ivoire, wild edible mushrooms harvested have a wide cultural acceptance and are a traditionally important nutritious food. However, there is no scientific data to define the appropriate stage to harvest these mushrooms for better nutritional needs. The present work aims to study the variation of chemical composition during mushrooms development. Thus, in this study, the proximate composition, mineral element profile and amino acid profile of three edible mushrooms ectomycorrhizal (Russula mustelina, Russula Delica and Russula Lepida) from Côte d'Ivoire were harvested at 3 different stages of maturity (immature, mature and post-mature) and investigated. The results showed a significant increase in Proteins, Ash, Crude fibers, Lipids and Energy values up to the stage post-mature, excepted carbohydrate contents which were high for all the species at immature stage; ash and reducing sugar were high at mature stage. Then they decrease with maturation. Mineral analysis of all species indicated the mushrooms were specifically rich in potassium, phosphorus and calcium at stage mature. They were found to be the most abundant mineral present in all specie in spite of their decrease during maturation. The mushrooms contained 17 amino acids among with the presence of all essential amino acids at immature stage. Also, these mushrooms could be considered a potential health food and may be of use to the food industry as a source of ingredients with high nutritional value at mature and post-mature stages.
\end{abstract}

Keywords: Wild mushrooms; Nutritional value; Mineral composition; Amino acid composition; Stage of maturity

\section{Introduction}

Mushrooms have been a part of human diet in many regions of the world for centuries due to organoleptic characteristic as well as the nutritional values [1]. Over the last decades, his consumption has significantly increased due to the scientific evidence of their ability to help the organism in the combat and prevention of several diseases [2, 3]. In nature, there are over 150000 species of mushrooms but only 10\% is known and designated [4]. Among them, around 2000 species are growned. Wild mushrooms are considered delicacy with high nutritional and functional value, and they are also accepted as nutraceutical foods; they are of considerable interest because of their organoleptic merit, medicinal properties, and economic significance $[5,6]$. Wild growing mushrooms have a worldwide distribution and have been a popular delicacy in many countries [7]. They can be grouped as functional food since their dietary components provides health benefit in cardiovascular and antioxidant properties, which are beyond basic nutrition [8]. Fruiting bodies of mushrooms are consumed as a delicacy for their texture and flavor, but also for their nutritional properties that makes them even more attractable $[3,9]$. Specifically, wild mushrooms are also described as an

\footnotetext{
${ }^{*}$ Corresponding author

E-mail address: konankouassihubert@yahoo.fr
} 
excellent choice to include in low caloric diets since they have high amounts of dietary fiber, minerals, vitamins, water, protein, carbohydrates, and low content in lipids [3, 10-11]. In Côte d'Ivoire, wild edible mushrooms are known and consumed in many households. In rural areas where they are abundant, most people collect them for home consumption as well as for extra income [12]. Recently, some studies concerning wild saprophytic edible mushrooms [13] and wild Ectomycorrhizal edible mushrooms [14-15] have been conducted on nutritional composition, bioactive compounds and antioxidant properties. However, these studies not examined the variation of chemical composition during mushrooms development to determine the stage of maturity with the best nutrient profile.

The aim of this research was to determine the appropriate stage to harvest three species of Russula from center of Côte d'Ivoire such as R. mustelina, $R$. delica and R. lepida fruit bodies for better nutritional requirements. Thus, these mushrooms were harvested at 3 different stages of maturity: immature, mature and post-mature. For this purpose, some biochemical parameters, minerals and amino acid profile were determined at these different stages of maturity.

\section{Material and methods}

\subsection{Sample Collection}

The sporocarps ectomycorrhizal of genus Russula were collected from their natural habitat at various locations across center region (Côte d'Ivoire). The type of vegetation at the sites of collection consisted of a typical clear forest. Collected samples were R. lepida, R. mustelina and R. delica. The fruiting bodies were harvested in different stages of maturity: immature (cap closed) and mature (cap opened) and post-mature (cap opened and mature spores). Collection was done between July 2016 and June 2018. After picking, the mushrooms were immediately transferred to the laboratory and cleaned from forest debris (without washing) with a plastic knife.

\subsection{Proximate analysis}

Dry matters were determined by drying in an oven at $105^{\circ} \mathrm{C}$ during $24 \mathrm{~h}$ to constant weight [16]. Crude protein was calculated from nitrogen (Nx6.25) obtained using the Kjeldahl method by AOAC [16]. Crude fat was determined by continuous extraction in a Soxhlet apparatus for $8 \mathrm{~h}$ using hexane as solvent [16]. Carbohydrate content was determined through the method used by Samant and Rege [17]. Total ash was determined by incinerating in a furnace at $550{ }^{\circ} \mathrm{C}[16]$. Method described by Dubois et al. [18] was used to determine total sugars while reducing sugars were analyzed according to the method of Bernfeld [19] using 3.5 dinitrosalycilic acids (DNS). The crude fibre contents were determined according to standard method [16]. The energy values of mushrooms were evaluated using formula described by Crisan and Sands [20].

Energy value $(\mathrm{kcal} / 100 \mathrm{~g})=(2.62 \times \%$ protein $)+(8.37 \times \%$ fat $)+(4.2 \times \%$ carbohydrate $)$

\subsection{Minerals analysis}

Minerals were determined employing AOAC [16] method. Flour was digested with a mixture of concentrated nitric acid $(14.44 \mathrm{~mol} / \mathrm{L})$, sulfuric acid $(18.01 \mathrm{~mol} / \mathrm{L})$ and perchloric acid $(11.80 \mathrm{~mol} / \mathrm{L})$ and analyzed using an atomic absorption spectrophotometer. The total phosphorus was determined as orthophosphate by the ascorbic acid method after acid digestion and neutralization using phenolphthalein indicator and combined reagent [21].

\subsection{Statistical analysis}

All analyses were performed in triplicates. Results were expressed as mean values \pm standard deviation (SD). Analysis of variance (ANOVA) followed by Duncan's test was) performed to test for differences between means by employing Kyplot (version 2.0 beta 15, (C)1997-2001, Koichi Yoshioka statistical software. Significance of differences was defined at the $5 \%$ level $(\mathrm{p}<0.05)$.

\section{Results and discussion}

\subsection{Proximate Composition}

The results of the chemical composition and estimated energetic value obtained for the wild mushrooms species are shown in Table 1. 
Table 1 Proximate composition of three Russula species harvested at different stages of maturity

\begin{tabular}{|c|c|c|c|c|}
\hline \multirow[b]{2}{*}{ Parameters } & \multirow[b]{2}{*}{$\begin{array}{l}\text { Maturity } \\
\text { stages }\end{array}$} & \multicolumn{2}{|c|}{ Mushrooms species } & \multirow[b]{2}{*}{ R. delica } \\
\hline & & R. lepida & R. mustelina & \\
\hline \multirow{3}{*}{ Moisture (\%) } & I & $83.13 \pm 0.23^{\mathrm{a}_{A}}$ & $83.33 \pm 0.57^{\mathrm{a} A}$ & $84.93 \pm 0.31^{\mathrm{b}_{\mathrm{A}}}$ \\
\hline & II & $83.43 \pm 0.25^{\mathrm{a}_{A}}$ & $83.77 \pm 0.05^{\mathrm{b}_{A}}$ & $85.31 \pm 0.01^{c_{A}}$ \\
\hline & III & $84.27 \pm 0.46^{\mathrm{b}_{\mathrm{B}}}$ & $83.43 \pm 0.05^{\mathrm{a}_{A}}$ & $85.21 \pm 0.10^{c_{A}}$ \\
\hline \multirow{3}{*}{ Dry matter (\%) } & I & $16.87 \pm 0.23^{\mathrm{a} B}$ & $16.67 \pm 0.57^{\mathrm{a}_{A}}$ & $15.07 \pm 0.31^{b_{A}}$ \\
\hline & II & $16.57 \pm 0.25^{c_{B}}$ & $16.23 \pm 0.05^{\mathrm{b}_{A}}$ & $14.69 \pm 0.01^{\mathrm{a}_{A}}$ \\
\hline & III & $15.73 \pm 0.46^{\mathrm{b}_{\mathrm{A}}}$ & $16.57 \pm 0.06^{\mathrm{c}_{\mathrm{A}}}$ & $14.79 \pm 0.10^{\mathrm{a}_{A}}$ \\
\hline \multirow{3}{*}{ Crude Fibre (\%) } & I & $07.57 \pm 0.00^{\mathrm{a}_{A}}$ & $08.89 \pm 0.00^{\mathrm{b}_{\mathrm{A}}}$ & $15.78 \pm 0.15^{c_{A}}$ \\
\hline & II & $09.39 \pm 0.00^{\mathrm{b}_{B}}$ & $09.15 \pm 0.01^{\mathrm{aB}}$ & $16.45 \pm 0.01^{\mathrm{c}_{\mathrm{B}}}$ \\
\hline & III & $12.44 \pm 0.01^{\mathrm{b} C}$ & $11.21 \pm 0.00^{\mathrm{a} C}$ & $20.19 \pm 0.01^{\mathrm{c} \mathrm{C}}$ \\
\hline \multirow{3}{*}{ Proteins (\%) } & I & $29.39 \pm 0.01^{\mathrm{a}_{A}}$ & $33.28 \pm 0.01^{c_{A}}$ & $32.41 \pm 0.00^{\mathrm{b}_{\mathrm{A}}}$ \\
\hline & II & $37.04 \pm 0.03^{\mathrm{b}_{B}}$ & $36.02 \pm 0.00^{\mathrm{aB}}$ & $37.88 \pm 0.01^{c_{B}}$ \\
\hline & III & $38.64 \pm 0.03^{\mathrm{a} C}$ & $38.00 \pm 1.00^{\mathrm{a} C}$ & $39.02 \pm 0.01^{\mathrm{a} C}$ \\
\hline \multirow{3}{*}{ Fat $(\%)$} & $\mathrm{I}$ & $02.72 \pm 0.01^{\mathrm{a}_{A}}$ & $04.82 \pm 0.01^{\mathrm{b}_{\mathrm{A}}}$ & $05.80 \pm 0.00^{c_{A}}$ \\
\hline & II & $04.39 \pm 0.02^{\mathrm{a} B}$ & $05.10 \pm 0.01^{\mathrm{b}_{B}}$ & $06.45 \pm 0.00^{\mathrm{c}_{\mathrm{B}}}$ \\
\hline & III & $05.53 \pm 0.05^{\mathrm{a} C}$ & $06.12 \pm 0.02^{b_{C}}$ & $07.91 \pm 0.02^{c_{C}}$ \\
\hline \multirow{3}{*}{ Carbohydrates (\%) } & I & $47.74 \pm 0.00^{c_{C}}$ & $42.51 \pm 0.01^{\mathrm{a} C}$ & $44,97 \pm 0,02^{b_{C}}$ \\
\hline & II & $41.37 \pm 0.01^{\mathrm{b}_{\mathrm{A}}}$ & $41.32 \pm 0.00^{c_{B}}$ & $37,31 \pm 0,00^{\mathrm{a} B}$ \\
\hline & III & $41.14 \pm 0.01^{b_{B}}$ & $40.35 \pm 0.05^{\mathrm{a}_{A}}$ & $35,61 \pm 0,02^{\mathrm{a}_{\mathrm{A}}}$ \\
\hline \multirow{3}{*}{ Ash (\%) } & I & $09.49 \pm 0.00^{\mathrm{a}_{A}}$ & $10.53 \pm 0.01^{\mathrm{b}_{\mathrm{A}}}$ & $12.46 \pm 0.01^{\mathrm{c}_{\mathrm{A}}}$ \\
\hline & II & $12.43 \pm 0.02^{\mathrm{aB}}$ & $12.66 \pm 0.00^{\mathrm{b}_{\mathrm{B}}}$ & $13.36 \pm 0.05^{c_{B}}$ \\
\hline & III & $15.15 \pm 0.00^{b_{C}}$ & $14.39 \pm 1.01^{\mathrm{a} A}$ & $15.82 \pm 0.00^{\mathrm{c}_{\mathrm{C}}}$ \\
\hline \multirow{3}{*}{ Total Sugars (\%) } & I & $15.63 \pm 0.01^{\mathrm{aB}}$ & $17.90 \pm 0.01^{\mathrm{c} B}$ & $16.63 \pm 0.00^{\mathrm{b}_{\mathrm{B}}}$ \\
\hline & II & $18.77 \pm 0.00^{\mathrm{aC}}$ & $20.08 \pm 0.04^{\mathrm{b}_{\mathrm{C}}}$ & $18.77 \pm 0.02^{\mathrm{a} C}$ \\
\hline & III & $14.62 \pm 0.00^{\mathrm{a}_{A}}$ & $17.01 \pm 0.01^{c_{A}}$ & $15.93 \pm 0.02^{c_{A}}$ \\
\hline \multirow{3}{*}{ Reducing Sugar (\%) } & $\mathrm{I}$ & $00.32 \pm 0.01^{b_{A}}$ & $00.26 \pm 0.02^{\mathrm{a}_{A}}$ & $00.36 \pm 0.00^{c_{A}}$ \\
\hline & II & $00.45 \pm 0.05^{\mathrm{a}_{\mathrm{B}}}$ & $00.41 \pm 0.00^{\mathrm{a} C}$ & $00.90 \pm 0.20^{\mathrm{b}_{B}}$ \\
\hline & III & $00.38 \pm 0.00^{\mathrm{b}_{A}}$ & $00.34 \pm 0.01^{\mathrm{a} B}$ & $00.44 \pm 0.01^{c_{A}}$ \\
\hline \multirow{3}{*}{$\begin{array}{l}\text { Energy } \\
\text { Kcal/100g MS }\end{array}$} & I & $264.91 \pm 0.00^{\mathrm{a}_{A}}$ & $273.31 \pm 0.01^{\mathrm{b}_{\mathrm{A}}}$ & $279.16 \pm 0.00^{c_{B}}$ \\
\hline & II & $273.99 \pm 0.01^{\mathrm{a} B}$ & $278.08 \pm 0.06^{b_{B}}$ & $288.54 \pm 0.01^{c_{A}}$ \\
\hline & III & $288.01 \pm 0.01^{\mathrm{b} C}$ & $287.99 \pm 0.00^{\mathrm{a} C}$ & $288.61 \pm 0.00^{c_{C}}$ \\
\hline
\end{tabular}

Each value is an average of three replicate, Values are mean \pm standard deviation, Means not sharing a similar tiny letter in a line and capital letter in a column are significantly different $\mathrm{P} \leq 0.05$ as assessed by the test of Duncan.

Concerning dry matter of the three mushrooms species (R. lepida, $R$. mustella and $R$. delica) ranged between 15.73$16.87 \%$; 16.23-16.67 \%; 14.69-15.07 \% respectively (Table 1). So, high values of moistures were observed but, they remain constant during maturation for same species. It is important to consider moisture content, since all the nutrients are contained in the dry matter of food. Dry matter levels as high as $20 \%$ have been reported for some species, however $10 \%$ or less is common [22,23]. The content of dry matter in the three edible wild mushrooms falls within ranges of reported data. The high moisture content of the three mushroom species indicates that they are highly perishable. High moisture content has been reported to promote susceptibility to microbial growth and enzyme activity which accelerates spoilage [24]. 
Carbohydrates significantly decreased during maturation $(47.74$ to $41.14 \%$ for R. lepida; 42.51 to 40 . $35 \%$ for R. mustelina and 44.97 to $35.61 \%$ for R. delica). The decrease in carbohydrate content may be explained by their energetic role, being catabolized for energy production along the mushroom growth. For the three species, total sugars found in mature stage were significantly $(\mathrm{p}<0.05)$ high than the contents found in the Immature and postmature stages. Moreover, other authors observed for different species (R. lepida, R. mustella and R. delica) a total free monosaccharide of mushrooms increase in mature stage, as compared with immature mushrooms.

While proteins increase of 29.39 to $38.64 \%$ for R. lepida; 33.28 to $38.00 \%$ for R. mustelina and 32.41 to $39.02 \%$ for $R$. delica. These values attained a highest starting from the mature stage. Otherwise, the increase in protein (mainly structural compounds) content may be due to the protein synthesis inherent to mushrooms maturity [25].

Interestingly, fibers content increased with maturation. Crude fibers content greatly increased until post-matur stage. Thus, the consumption of mushrooms at post-mature could cover the daily need for soluble fibers which is estimated to be between 25 and $30 \mathrm{~g}$ [26] and would contribute to reducing the risks of hypertension, constipation, diabetes, colon cancer and breast, since soluble fibers decreases the absorption of cholesterol and glucose in the blood [27].

However, the content of reducing sugar content peaked at stage II and greatly decreased at post-mature stage. The difference between carbohydrate and reducing sugar contents is the content of soluble polysaccharides, which were thought to be biologically active substances in mushrooms [28].

The ash content increased with maturation in three species. This variation in ash content among results of different studies is probably caused by variations in edaphic environmental factors, which have direct bearing to mineral contents of mushrooms.

In terms of energy values, the results indicated that the three mushrooms species wild edible analyzed at different stages of fruiting body maturity increased in calorie content and their energy value increased according to stage (Table 1). In all varieties the stage III in caloric value was highest for $R$. lepida $(288.01 \mathrm{Kcal} / 100 \mathrm{~g}$ dry matter), followed by R. mustelina (287.99 Kcal/100g dry matter) while R. delica recorded the lowest $(288.61 \mathrm{Kcal} / 100 \mathrm{~g}$ dry matter). Owing to their high content of water and low caloric value mushrooms could be considered as a dietetic food, suitable for low-calorie diets. The variations observed on the chemical composition during maturation indicate that the gatherings of mushrooms could be done from the mature stage. At this stage, these components are in quantity allowing a good functioning of organism $[29,30]$.

\subsection{Mineral composition}

Minerals represent the ash left behind after complete incineration of the dry mushroom. The mineral composition reflects on the growth conditions of the mushroom. The major mineral composition of these mushrooms shown in Table 2. Minerals such as potassium, calcium are said to be major because they are in high concentrations of the mushroom, as well as phosphorus and magnesium. However, sodium is relatively less in mushroom species; thus, mushrooms are said to be good for patients with hypertension [31,32].

The results in table 3 show micromineral composition. Mineral content peaked at stage II and greatly decreased when post-mature. The results of micromineral values of the three edibles species of mushrooms during maturation clearly indicate the potential for their use as sources of good quality food. The mineral levels, in these mushrooms were appreciably near than those reported for several cowpea varieties [33], but lower than those reported for fish, snails and broiler meat [34]. Using this proximate analysis, the mineral and analytical food value as approximate indices of nutritional quality, it would appear that some of these mushrooms fall between most legumes and meat. In earlier studies, [35] indicated that edible mushrooms were highly nutritional and compared favorably with meat, egg and milk. Some of the mushrooms are known to possess antitumorigenic and hypocholesterolaemic agents, which implies that mushrooms could hold special attraction for and may be recommended for people with cholesterol-related ailments [36, 37]. 
Table 2 Major mineral content of three Russula species harvested at different stages of maturity

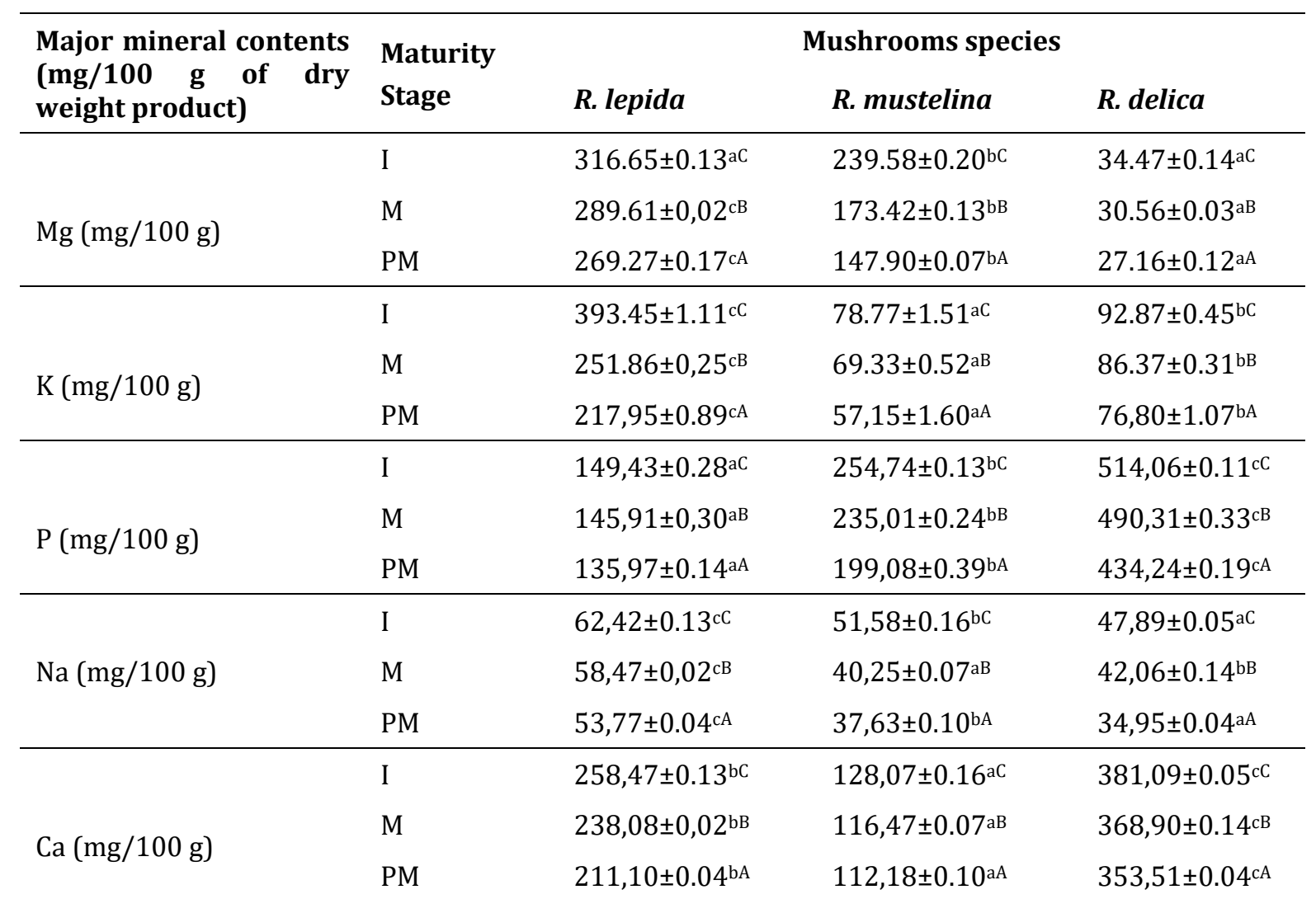

Each value is an average of three replicate, Values are mean \pm standard deviation, Means not sharing a similar tiny letter in a line and capital letter in a column are significantly different $\mathrm{P} \leq 0.05$ as assessed by the test of Duncan.

Table 3 Trace mineral content of three Russula species harvested at different stages of maturity

\begin{tabular}{|c|c|c|c|c|}
\hline \multirow{2}{*}{$\begin{array}{l}\text { Trace mineral } \\
\text { contents }(\mathrm{mg} / 100 \mathrm{~g} \text { of } \\
\text { dry weight product) }\end{array}$} & \multirow{2}{*}{$\begin{array}{l}\text { Maturity } \\
\text { stages }\end{array}$} & \multicolumn{3}{|c|}{ Mushrooms species } \\
\hline & & R. lepida & R. mustelina & R. delica \\
\hline \multirow{3}{*}{$\mathrm{Mn}(\mathrm{mg} / 100 \mathrm{~g})$} & $\mathrm{I}$ & $07.06 \pm 0.04^{\mathrm{cC}}$ & $06.95 \pm 0.08^{\mathrm{bB}}$ & $05.04 \pm 0.06^{\mathrm{aB}}$ \\
\hline & M & $02.37 \pm 0.04^{\mathrm{aB}}$ & $06.33 \pm 0.05^{\mathrm{cA}}$ & $04.98 \pm 0.08^{\mathrm{bA}}$ \\
\hline & PM & $01.54 \pm 0.05^{\mathrm{aA}}$ & $06.32 \pm 0.06^{\mathrm{cA}}$ & $04.69 \pm 0.04 \mathrm{bA}$ \\
\hline \multirow{3}{*}{$\mathrm{Fe}(\mathrm{mg} / 100 \mathrm{~g})$} & I & $48.37 \pm 0.10^{\mathrm{bC}}$ & $25.67 \pm 0.36^{\mathrm{aC}}$ & $57.69 \pm 0.42^{\mathrm{cC}}$ \\
\hline & M & $24.35 \pm 0.07 \mathrm{bB}$ & $16.79 \pm 0.52^{\mathrm{aB}}$ & $25.22 \pm 0.16^{\mathrm{cB}}$ \\
\hline & PM & $16.23 \pm 0.08^{\mathrm{bA}}$ & $15.83 \pm 0.20^{\mathrm{aA}}$ & $20.08 \pm 0.30^{\mathrm{cA}}$ \\
\hline \multirow{3}{*}{$\mathrm{Cu}(\mathrm{mg} / 100 \mathrm{~g})$} & I & $02.27 \pm 0.01^{\mathrm{aA}}$ & $03.70 \pm 0.07 \mathrm{cC}$ & $02.82 \pm 0.04 \mathrm{bC}$ \\
\hline & M & $02.45 \pm 0.01^{\mathrm{bB}}$ & $02.78 \pm 0.08^{\mathrm{cB}}$ & $02.36 \pm 0.02^{\mathrm{aB}}$ \\
\hline & PM & $02.42 \pm 0.19^{\mathrm{cB}}$ & $01.69 \pm 0.03^{\mathrm{bA}}$ & $01.38 \pm 0.09^{\mathrm{aA}}$ \\
\hline \multirow{3}{*}{ Zn (mg/100 g) } & I & $10.32 \pm 0,03^{\mathrm{bc}}$ & $07.26 \pm 0.03^{\mathrm{aC}}$ & $12.56 \pm 0.01^{\mathrm{cC}}$ \\
\hline & M & $08.02 \pm 0.03^{\mathrm{bB}}$ & $02.86 \pm 0.01^{\mathrm{aB}}$ & $10.37 \pm 0.05^{\mathrm{cB}}$ \\
\hline & PM & $03.72 \pm 0.05^{\mathrm{bA}}$ & $01.34 \pm 0.03^{\mathrm{aA}}$ & $07.32 \pm 0.03^{\mathrm{cA}}$ \\
\hline
\end{tabular}

Each value is an average of three replicate, Values are mean \pm standard deviation, Means not sharing a similar tiny letter in a line and capital letter in a column are significantly different $\mathrm{P} \leq 0.05$ as assessed by the test of Duncan. 


\subsection{Amino acids composition}

The analysis of extracts from three species of Russula harvested during their development by HPLC is presented in table 4 and 5.

Table 4 Non-essential Amino acids profile of three Russula species at different maturity stages

\begin{tabular}{|c|c|c|c|c|}
\hline \multirow{2}{*}{ Amino Acids } & \multirow{2}{*}{$\begin{array}{l}\text { Maturity } \\
\text { stages }\end{array}$} & \multicolumn{3}{|c|}{ Mushroom samples } \\
\hline & & Russula Lepida & Russula mustelina & Russula Delica \\
\hline \multirow{3}{*}{ Cysteine } & I & $1.80 \pm 0.02^{\mathrm{aA}}$ & $1.05 \pm 0.04 \mathrm{bA}$ & $2.66 \pm 0.05^{\mathrm{cA}}$ \\
\hline & M & $3.16 \pm 0.04^{\mathrm{bB}}$ & $1.84 \pm 0.03^{\mathrm{aB}}$ & $3.65 \pm 0.15^{\mathrm{aB}}$ \\
\hline & PM & $3.78 \pm 0.03^{\mathrm{aC}}$ & $2.57 \pm 0.03^{\mathrm{aC}}$ & $3.80 \pm 0.03^{\mathrm{bc}}$ \\
\hline \multirow{3}{*}{ Tyrosine } & I & $1.79 \pm 0.03^{\mathrm{cA}}$ & $1.43 \pm 0.03^{\mathrm{aB}}$ & $1.50 \pm 0.02^{\mathrm{bA}}$ \\
\hline & M & $1.83 \pm 0.03^{\mathrm{bB}}$ & $1.62 \pm 0.03^{\mathrm{aC}}$ & - \\
\hline & PM & $2.53 \pm 0.03^{\mathrm{cC}}$ & $1.20 \pm 0.03^{\mathrm{aA}}$ & $1.75 \pm 0.03^{\mathrm{bB}}$ \\
\hline \multirow{3}{*}{ Arginine } & I & $3.25 \pm 0.05^{\mathrm{cA}}$ & $1.91 \pm 0.02^{\mathrm{aA}}$ & $2.41 \pm 0.02^{\mathrm{bA}}$ \\
\hline & M & $4.19 \pm 0.03^{\mathrm{cC}}$ & $2.73 \pm 0.04 \mathrm{bB}$ & $2.59 \pm 0.02^{\mathrm{aA}}$ \\
\hline & $\mathrm{PM}$ & $3.43 \pm 0.05^{\mathrm{bB}}$ & $3.56 \pm 0.05^{\mathrm{cC}}$ & $3.12 \pm 0.03^{\mathrm{aB}}$ \\
\hline \multirow{3}{*}{ Glutamic acid } & I & $0.23 \pm 0.02^{\mathrm{bA}}$ & $0.41 \pm 0.01^{\mathrm{cA}}$ & $0.06 \pm 0.01^{\mathrm{aA}}$ \\
\hline & M & $0.28 \pm 0.02^{\mathrm{aB}}$ & $0.47 \pm 0.04^{\mathrm{cB}}$ & $0.44 \pm 0.03^{\mathrm{bB}}$ \\
\hline & PM & $0.35 \pm 0.01^{\mathrm{aC}}$ & $0.46 \pm 0.05^{\mathrm{bB}}$ & - \\
\hline \multirow{3}{*}{ Alanine } & I & $5.28 \pm 0.05^{\mathrm{cA}}$ & $2.09 \pm 0.04^{\mathrm{aA}}$ & $2.71 \pm 0.01^{\mathrm{bA}}$ \\
\hline & M & $5.64 \pm 0.04^{\mathrm{cB}}$ & $3.70 \pm 0.03^{\mathrm{bB}}$ & $2.89 \pm 0.01 \mathrm{aB}$ \\
\hline & PM & - & $3.94 \pm 0.05^{b c}$ & $3.03 \pm 0.04^{\mathrm{aC}}$ \\
\hline \multirow{3}{*}{ Glycine } & I & - & $1.51 \pm 0.03^{\mathrm{bA}}$ & $0.03 \pm 0.01^{\mathrm{aA}}$ \\
\hline & M & $1.73 \pm 0.03^{\mathrm{aA}}$ & $4.71 \pm 0.02^{\mathrm{bB}}$ & - \\
\hline & PM & $2.04 \pm 0.03^{\mathrm{bB}}$ & - & $1.03 \pm 0.03^{\mathrm{aB}}$ \\
\hline \multirow{3}{*}{ Serine } & I & $0.04 \pm 0.01^{\mathrm{aA}}$ & $7.79 \pm 0.04^{\mathrm{cA}}$ & $0.07 \pm 0.05^{\mathrm{bA}}$ \\
\hline & M & $0.73 \pm 0.04^{\mathrm{aC}}$ & $8.00 \pm 0.02^{\mathrm{bB}}$ & - \\
\hline & PM & $0.26 \pm 0.02^{\mathrm{aB}}$ & $8.04 \pm 0.05^{\mathrm{cC}}$ & $0.77 \pm 0.62^{\mathrm{bB}}$ \\
\hline \multirow{3}{*}{ Proline } & I & $9.30 \pm 0.05^{\mathrm{cB}}$ & $7.50 \pm 0.02^{\mathrm{bB}}$ & $0.71 \pm 0.02^{\mathrm{aA}}$ \\
\hline & M & $7.91 \pm 0.03^{\mathrm{bA}}$ & $3.75 \pm 0.05^{\mathrm{aA}}$ & - \\
\hline & PM & - & $8.90 \pm 0.02^{\mathrm{aC}}$ & - \\
\hline
\end{tabular}

Each value is an average of three replicate, Values are mean \pm standard deviation, Means not sharing a similar tiny letter in a line and capital letter in a column are significantly different $\mathrm{P} \leq 0.05$ as assessed by the test of Duncan.

It allowed the identification of seventeen essential and non-essential amino acids such as valine, phenylalanine, threonine, tryptophan histidine, isoleucine, leucine, lysine, methionine, arginine, cysteine, alanine, glycine, proline, serine, tyrosine and glutamic acid. For three species, the result showed the presence of all essential and non-essential amino acids at mature stage. Then, their content decreases significantly $(p<0.05)$ to total disappearance at postmature stage for certain and others increases significantly $(\mathrm{p}<0.05)$ to the post-mature stage except, phenylalanine which are absent in R. lepida and R. delica, as well as isoleucine and proline which were absent in R. delica. This characteristic is in agreement with those reported by Beluhan and Ranogajec [38] and Kouassi et al. [15]. The 
variations of amino acids contents observed during the maturation of mushrooms could be due to the transamination and dehydrogenation undergo by them. A small part of them probably emitted as volatile hydroxyl acids such as isobutanoic acid, hexanoic acid and octanoic acid under the action of aminotransferase [39].

Table 5 Essential Amino acids profile of three Russula species at different maturity stages

\begin{tabular}{|c|c|c|c|c|}
\hline \multirow{2}{*}{ Amino acids } & \multirow{2}{*}{$\begin{array}{l}\text { Maturity } \\
\text { stages }\end{array}$} & \multicolumn{3}{|c|}{ Mushroom samples } \\
\hline & & Russula lepida & Russula mustelina & Russula delica \\
\hline \multirow{3}{*}{ Lysine* } & I & $2.35 \pm 0.03^{\mathrm{cA}}$ & $2.04 \pm 0.04^{\mathrm{bA}}$ & $1.84 \pm 0.03^{\mathrm{aA}}$ \\
\hline & M & $2.41 \pm 0.03^{\mathrm{bB}}$ & $2.62 \pm 0.03^{\mathrm{cB}}$ & $2.04 \pm 0.03^{\mathrm{aB}}$ \\
\hline & PM & $2.91 \pm 0.06^{\mathrm{bC}}$ & $2.77 \pm 0.07 \mathrm{aC}$ & $3.71 \pm 0.05^{\mathrm{cB}}$ \\
\hline \multirow{3}{*}{ Threonine* } & I & $2.51 \pm 0.02^{\mathrm{bB}}$ & $2.16 \pm 0.05^{\mathrm{bA}}$ & $2.06 \pm 0.05^{\mathrm{aA}}$ \\
\hline & M & $2.49 \pm 0.02^{\mathrm{cB}}$ & $2.27 \pm 0.04^{\mathrm{bB}}$ & $2.15 \pm 0.05^{\mathrm{aB}}$ \\
\hline & $\mathrm{PM}$ & $2.18 \pm 0.02^{\mathrm{aA}}$ & $2.40 \pm 0.04^{\mathrm{aC}}$ & $2.85 \pm 0.04 \mathrm{bC}$ \\
\hline \multirow{3}{*}{ Methionine* } & I & $0.71 \pm 0.06^{\mathrm{aA}}$ & $0.73 \pm 0.04^{\mathrm{aA}}$ & $0.07 \pm 0.02^{\mathrm{aA}}$ \\
\hline & M & $0.75 \pm 0.03^{\mathrm{aB}}$ & $1.26 \pm 0.03^{\mathrm{bB}}$ & $0.71 \pm 0.05^{\mathrm{aB}}$ \\
\hline & $\mathrm{PM}$ & $0.83 \pm 0.02^{\mathrm{aC}}$ & $0.74 \pm 0.04^{\mathrm{aA}}$ & $1.74 \pm 0.05^{\mathrm{bB}}$ \\
\hline \multirow{3}{*}{ Isoleucine* } & I & $2.24 \pm 0.04^{\mathrm{bA}}$ & $1.63 \pm 0.03^{\mathrm{aA}}$ & - \\
\hline & M & $4.05 \pm 0.06^{\mathrm{bB}}$ & $2.21 \pm 0.02^{\mathrm{aB}}$ & - \\
\hline & $\mathrm{PM}$ & $4.19 \pm 0.06^{\mathrm{cC}}$ & $3.73 \pm 0.03^{\mathrm{aC}}$ & $5.72 \pm 0.02^{\mathrm{aA}}$ \\
\hline \multirow{3}{*}{ Valine* } & I & $3.83 \pm 0.05^{\mathrm{bB}}$ & - & $2.24 \pm 0.05^{\mathrm{aA}}$ \\
\hline & M & $3.79 \pm 0.04^{\mathrm{aA}}$ & $3.97 \pm 0.05^{\mathrm{bA}}$ & $4.73 \pm 0.05^{\mathrm{cB}}$ \\
\hline & $\mathrm{PM}$ & $4.10 \pm 0.06^{\mathrm{aC}}$ & $4.60 \pm 0.02^{\mathrm{bB}}$ & - \\
\hline \multirow{3}{*}{ Phenylalanine* } & I & - & $2.30 \pm 0.03^{\mathrm{aC}}$ & - \\
\hline & M & - & $2.16 \pm 0.04^{\mathrm{aB}}$ & - \\
\hline & PM & - & $1.93 \pm 0.04^{\mathrm{aA}}$ & - \\
\hline \multirow{3}{*}{ Histidine* } & I & $0.23 \pm 0.05^{\mathrm{aA}}$ & $1.15 \pm 0.04 \mathrm{cA}$ & $0.96 \pm 0.02^{\mathrm{bA}}$ \\
\hline & M & $1.12 \pm 0.03^{\mathrm{aB}}$ & $1.50 \pm 0.02^{\mathrm{bB}}$ & $1.62 \pm 0.04^{\mathrm{cB}}$ \\
\hline & $\mathrm{PM}$ & $1.95 \pm 0.04^{\mathrm{aC}}$ & $1.95 \pm 0.04^{\mathrm{aC}}$ & $1.95 \pm 0.04^{\mathrm{aC}}$ \\
\hline \multirow{3}{*}{ Tryptophane* } & I & $0.46 \pm 0.04^{\mathrm{aA}}$ & $0.40 \pm 0.02^{\mathrm{aA}}$ & $0.42 \pm 0.04^{\mathrm{aA}}$ \\
\hline & M & $0.42 \pm 0.03^{\mathrm{aA}}$ & $0.43 \pm 0.05^{\mathrm{aB}}$ & $0.42 \pm 0.03^{\mathrm{aA}}$ \\
\hline & $\mathrm{PM}$ & $0.40 \pm 0.02^{\mathrm{aA}}$ & $0.45 \pm 0.04^{\mathrm{aB}}$ & $1.43 \pm 0.02^{\mathrm{aA}}$ \\
\hline \multirow{3}{*}{ Leucine* } & $\mathrm{I}$ & $4.47 \pm 0.06^{\mathrm{cB}}$ & $3.09 \pm 0.03^{\mathrm{bA}}$ & $2.36 \pm 0.03^{\mathrm{aA}}$ \\
\hline & M & $4.30 \pm 0.02^{\mathrm{cA}}$ & $3.53 \pm 0.04^{\mathrm{bB}}$ & $3.11 \pm 0.01^{\mathrm{aB}}$ \\
\hline & PM & - & $3.62 \pm 0.03^{\mathrm{aC}}$ & $7.90 \pm 0.02^{\mathrm{bc}}$ \\
\hline \multirow{3}{*}{$\begin{array}{l}\text { Essential Amino acids } \\
\text { (AAE) }\end{array}$} & I & $16.8 \pm 1.05^{\mathrm{cB}}$ & $13.5 \pm 1.03^{\mathrm{bA}}$ & $9.95 \pm 1.04^{\mathrm{aA}}$ \\
\hline & M & $19.34 \pm 1.06^{\mathrm{bC}}$ & $19.94 \pm 1.04 \mathrm{cB}$ & $14.78 \pm 1.06^{\mathrm{cB}}$ \\
\hline & PM & $16.58 \pm 1.04^{\mathrm{bA}}$ & $22.17 \pm 1.02^{\mathrm{bc}}$ & $25.3 \pm 1.04 \mathrm{cC}$ \\
\hline \multirow{3}{*}{$\begin{array}{l}\text { Total } \\
\text { (AAT) }\end{array}$} & $\mathrm{I}$ & $38.49 \pm 1.04^{\mathrm{aA}}$ & $37.19 \pm 1.02^{\mathrm{bA}}$ & $20.1 \pm 1.03^{\mathrm{aA}}$ \\
\hline & $\mathrm{M}$ & $44.81 \pm 1.03^{\mathrm{bC}}$ & $46.76 \pm 1.03^{\mathrm{cB}}$ & $24.35 \pm 1.03^{\mathrm{aB}}$ \\
\hline & PM & $28.97 \pm 1.02^{\mathrm{aA}}$ & $50.84 \pm 1.06^{\mathrm{cC}}$ & $38.80 \pm 0.04 \mathrm{cC}$ \\
\hline \multirow{3}{*}{ AAE / AAT } & $\mathrm{I}$ & 0.43 & 0.36 & 0.49 \\
\hline & M & 0.43 & 0.42 & 0.60 \\
\hline & PM & 0.57 & 0.43 & 0.65 \\
\hline
\end{tabular}

Each value is an average of three replicate, Values are mean \pm standard deviation, Means not sharing a similar tiny letter in a line and capital letter in a column are significantly different $\mathrm{P} \leq 0.05$ as assessed by the test of Duncan

Nevertheless, these studies suggested that, as demonstrated in our work, the amino acid contents in mushrooms were considerably divergent between species. In addition, the different geographical origin, growth conditions, and harvesting times of the analyzed species cannot be excluded. Likewise, the contents of eight (8) essential amino acids (AAE) have been revealed of the different maturity stages (immature, mature and post-mature) and are respectively 
$(38.49,44.81$ and $28.97 \mathrm{~g} / 100 \mathrm{~g})$ in R. lepida; (37.19, 46.76 and 50.84g / 100g) in R.mustelina; $(20.1,24.35$ and $38.8 \mathrm{~g}$ $/ 100 \mathrm{~g}$ ) in R. delica. Also, the AAE / AAT ratios obtained during development (immature, mature and post-mature) are respectively $(0.43,0.43$ and $0.57 \mathrm{~g} / 100 \mathrm{~g})$ in $\mathrm{R}$. lepida; $(0.36,0.42$ and $0.43 \mathrm{~g} / 100 \mathrm{~g})$ in $\mathrm{R}$. mustelina; $(0.49,0.60$ and $0.65 \mathrm{~g} / 100 \mathrm{~g}$ ) in R. delica. The amino acid values obtained from the three wild edible fungi all significantly change (P> 0.05 ) as a function of maturation. With regard to amino acids, it is good to signify that they play an essential role in the repair, cell growth of tissues and organs $[40,41]$. The levels of AA are relatively higher than those obtained by Fabiane et al. [42]. However, there is generally a change in levels during ripening. Indeed, this evolution is probably related to the processes of protein synthesis during maturation [43]. In addition, according to Bernas and Jaworska (2010) [44], when the AAE / AAT ratio is greater than or equal to 50\%, this means a good availability of PPAs to meet the minimum daily needs. In view of the results obtained, the mushrooms studied harvested after the mature stage could be an interesting source of amino acids for consumers.

\section{Conclusion}

The knowledge about their chemical composition in different maturity stages of fruiting body will be also useful in order to find the best stage to achieve better functional and nutritional properties. In this study, we can conclude that the second stage of maturity is that recommended for the harvest of these mushrooms. Thus, the mushroom consumers will be able to really profit from their food value.

\section{Compliance with ethical standards}

\section{Acknowledgments}

We also express our gratitude to Dr. Ir. Nourou S. YOROU (University of Munich, Tropical Mycology, Department Biology I, Organismic Biology, Germany) for contribution on identification of the three edible mushrooms used in the present study.

\section{Disclosure of conflict of interest}

All authors declare no conflict of interest.

\section{References}

[1] Wang Y and Xu B. (2014). Distribution of antioxidant activities and total phenolic contents in acetone, ethanol, water and hot water extracts from 20 edible mushrooms via sequential extraction. Austin Journal of Nutrition and Food Sciences, 2(1), 1-5.

[2] Ferreira ICFR, Barros L and Abreu RMV. (2009). Antioxidants in wild mushrooms. Current Medicinal Chemistry, $16,1543-1560$.

[3] Kalac P. (2012). Chemical composition and nutritional value of European species of wild growing mushrooms, In Mushrooms: types, properties and nutrition. Editors: S. Andres and N. Baumann. Nova Science Publishers, 130-151.

[4] Wasser SP. (2010). Medicinal mushroom science: history, current status, future trends, and unsolved problems. International Journal of Medicinal Mushrooms, 12(1), 1-16.

[5] Chang ST and Miles PG. (2008). Mushrooms: cultivation, nutritional value, medicinal effect, and environmental impact (2nd ed.). Boca Raton, FL: CRC Press.

[6] Ergonul PG, Akata I, Kalyoncu F and Ergonul B. (2013). Fatty acid compositions of six wild edible mushroom species. The Scientific World Journal, Article ID 163964, 4.

[7] Valentão P, Lopes G, Valente M, Barbosa P, Andrade PB, Silva BM and Seabra, RM. (2005). Quantitation of nine organic acids in wild mushrooms. Journal of agricultural and food chemistry, 53(9), 3626-3630.

[8] Ferreira ICFR, Vaz JA, Vasconcelos MH and Martins A. (2010). Compounds from wild mushrooms with antitumor potential. Anticancer Agents in Medicinal Chemistry, 10, 424-436. 
[9] Lindequist U, Niedermeyer, THJ and Julich WD. (2005). The pharmacological potential of mushrooms. Evidencebased Complementary and Alternative Medicine (eCAM), 2, 285-299.

[10] Mattila P, Konko K, Eurola M, Pihlava J M, Astola J, Vahteristo L, Hietaniemi V, Kumpulainen J, Valtonen M and Piironen V. (2001). Contents of vitamins, mineral elements, and some phenolic compounds in cultivated mushrooms. Journal of Agricultural and Food Chemistry, 49, 2343-2348.

[11] Heleno SA, Barros L, Sousa MJ, Martins A and Ferreira ICFR. (2009). Study and characterization of selected nutrients in wild mushrooms from Portugal by gas chromatography and high performance liquid chromatography. Microchem J, 93(2), 195-199.

[12] Koné NA, Yéo K, Konaté S and Linsenmair KE. (2013). Socio-economical aspects of the exploitation of Termitomyces fruit bodies in central and southern Côte d'Ivoire: Raising awareness for their sustainable use. Journal of Applied Biosciences 70, 5580-5590.

[13] Atta HFA, Konan KH, Kouadio NEJP, Dué AE and Kouamé LP. (2016). Chemical composition and nutritional value of two edible mushrooms from three regions of Côte d'Ivoire J. basic appl. Res 2(2), 117-123.

[14] Kouassi KA, Konan KH, Kouadio NEJP and Kouamé LP. (2015). Nutritional composition of three edible ectomycorrhizal mushrooms from Center of Côte d'Ivoire. International Journal of Biosciences, 7(4), $120-127$.

[15] Kouassi KA, Konan KH, Kouadio NEJ P and Kouamé LP. (2016). Proximate composition, minerals and amino acids profiles of selected wild edible Russula species from Côte d'Ivoire. Turkish Journal of Agriculture - Food Science and Technology, 4(10), 882-886.

[16] AOAC. (1990). Official methods of analysis. 14th Edn, Association of Official Analytical Chemists, Washington DC.

[17] Samant SK and Rege DV. (1989).Carbohydrate Composition of Some Cucurbit Seeds. Journal of Food Composition and Analysis 2, 149-156.

[18] Dubois M, Gilles KA, Hamilton JK, Rebers PA and Smith F. (1956). Colorimetric method for determination of sugars and related substances. Analytical Chemistry, 28(3), 350-356.

[19] Bernfeld P. (1955). Amylases, $\alpha$ and $\beta$. Methods Enzymol, 1, 149-158.

[20] Crisan EV and Sands A. (1978). The biology and cultivation of edible mushrooms, Nutritional value, Academic Press, New York, 137-168.

[21] APHA. 1995. Standard methods for examination of water and waste water, 19th ed., American Public Health Association, USA.

[22] Źródlowisk Z. (1995). The effect of washing and peeling of mushrooms Agaricus bisporus on the level of heavy metal contamination. Pol. J. Food.Nutr. Sci. 4(45), 26-33.

[23] Manzi I, Gambelli L, Mariconi S, Vivanti V and Pizzoferrato L. (1999). Nutrients in edible mushrooms:an interspecies comparative study. Food Chemistry. (Day and Underwood) 65, 477-482.

[24] Anthony MM and Joyce C. (2007). Proximate and nutrient composition of three types of indigenous edible wild mushrooms grown in Tanzania and their utilization prospects. Africain Journal of Food Agriculture Nutrition and Development, 7 (24), 4551-4562.

[25] Lehninger AL. (2005). Biochemistry (4th Ed.). W.H. Freeman and Company Ed.: N.Y, USA.

[26] Depezay. (2006). Vegetables in the diet: their nutritional effects. Louis Bonduelle Foundation Ed., 7.

[27] Ishida H, Suzuno H, Sugiyama N, Innami S, Todokoro T and Maekawa A. (2000). Nutritional evaluation of chemical component of leaves stalks and stems of sweet potatoes (Ipomea batatas). Food Chemistry, 68, 359367.

[28] Wasser SP and Weis AL. (1999). Therapeutic effects of substances occurring in higher Basidiomycetes mushrooms: A modern perspective. Critical Reviews in Immunology, 19, 65-96.

[29] De Greef W, Delon R, De Block M, Leemans J and Botterman J. (1989). Evaluation of herbicide resistance in transgenic crops under field conditions. Nat. Biotechnol. 7, 61-64. 
[30] Manzi PA, Agguzzi A and Pizzoferrato L. (2001). Nutritional mushrooms widely consumed in Italy. Food Chemistry, 73, 321-325.

[31] Rajarathnam S, Shashirekha MN and Bano Z. (1998). Biodegradative and biosynthetic capacities of mushrooms: present and future strategies. Critical Reviews in Biotechnology, 18(2-3), 91-236.

[32] Mallikarjuna SE, Ranjini A, Haware DJ, Vijayalakshmi MR, Shashirekha MN and Rajarathnam, S. (2013). Mineral composition of four edible mushrooms. Journal of Chemistry, Article ID, 805284, 1-5.

[33] Adejumo TO and Awosanya OB. (2005). Proximate and mineral composition of four edible mushroom species from South Western Nigeria. African Journal of Biotechnology, 4(10), 1084-1088.

[34] Imevbore EA. (1992). Perspectives of snail farming in tropical Africa: the Nigerian situation. In: Proc. Invertebrates (Microlivestock) Farming Seminar, La Union, Philippines.

[35] Gruen VEC and Wong HX. (1982). Immunodulatory and Antitumour activities of a polysaccharide-peptide complex from a mycelial culture of Trichoderma sp. Sciences 57, 269-281.

[36] Chihara G. (1993). Medicinal aspects of Lentian isolated from Lentinus edodes (Berk). Hong Kong, Chinese Univ

[37] Teklit GA. (2015). Chemical composition and nutritional value of the most widely used mushrooms cultivated in Mekelle Tigray Ethiopia. Journal of Nutrition and Food Sciences, 5, 1-3.

[38] Beluhan S and Ranogajec A. (2011). Chemical composition and nonvolatile components of Croatian wild edible mushrooms. Food Chem, 124, 1076-1082.

[39] IOM (Institute of Medicine). (2016). Dietary Reference Intakes (DRIs): Recommended dietary allowances. Food and Nutrition Board, Institute of Medicine, National Academies.

[40] Schwab W, Davidovich-Rikanati R and Lewinsohn E. (2008). Biosynthesis of plant-derived flavor compounds. The Plant Journal, 54, 712-732.

[41] Wani BA, Bodha R H and Wani AH. (2010). Nutritional and medicinal importance of mushrooms. Journal of Medicinal Plants Research, 4, 2598-2604.

[42] Fabiane B, Cristiane VH, Marcelo BB, Giselle MM and Charles WIH. (2017). Edible mushrooms: a potential source of essential amino acids, glucans and minerals. International Journal of Food Science and Technology. 15-16.

[43] Jorg Ackermann, Monica F and Renato A. (1992). Changes in sugars, acids, and amino acids during ripening and storage of apples (Cv. Glockenapfel). J. Agrlc. Food Chem. 40, 1131-1 134.

[44] Bernas E and Jaworska G. (2010). Comparaison of amino acid content in frozen P. Ostreatus and A. Bisporus mushrooms. Acta Sci Pol 9(3), 295-303.

\section{How to cite this article}

Jaures GO, Appolinaire KK, Hubert KK, Jean Parfait KE. (2019). Proximate composition and nutritional value of three edible mushrooms ectomycorrhizal (Russula mustelina, Russula Delica and Russula Lepida) from Côte d'Ivoire according to the maturity stages. World Journal of Advanced Research and Reviews, 2(3), 21-30. 